\title{
Chainsaw Operators Perception on Occupational Health and Safety (OHS) in Industrial Plantation Forest, North Sumatra, Indonesia
}

\author{
Muhdi $^{1}$, Diana Sofia Hanafiah ${ }^{2}$, Wilda Rizki Lubis ${ }^{3}$, Alex Angenano Telaumbanua ${ }^{4}$, Dhea \\ Atika $^{5}$ \\ \{muhdi@usu.ac.id ${ }^{1 *}$,diana.hanafiah@usu.ac.id², wildarizki_lubis@ymail.com³ \\ alexte1556@yahoo.com ${ }^{4}$,dheaatika1@gmail.com ${ }^{5}$ \} \\ ${ }^{1,3,4}$ Faculty of Forestry, Universitas Sumatera Utara, Medan, Indonesia \\ ${ }^{2}$ Faculty of Agriculture, Universitas Sumatera Utara, Medan, Indonesia \\ *muhdi@usu.ac.id
}

\begin{abstract}
Logging activities in the industrial timber plantations uses mechanical equipment, namely chainsaw. The purpose of this study is to determine chainsaw operator's perceptions of the application and occupational safety and health based on aspects of knowledge, skills and attitudes in logging activities with chainsaw in industrial forest areas, North Sumatra, Indonesia. This research was conducted at PT. Toba Pulp Lestari, North Sumatra, Indonesia. The methods used in data collection are: interviews and observations. The choice of answers in the questionnaire for each respondent is determined based on a Likert scale. The value set for the respondent choice includes: knowledge, skill, and attitude. The results of the analysis on the competency of the felling respondents in each aspect, namely knowledge, skills and attitude have values was 4.08 , 4.17 and 4.1, respectively. This research indicates that there are significant differences between chainsaw operator's perceptions.
\end{abstract}

Keywords: chainsaw operators, perception, occupational health and safety.

\section{Introduction}

Timber harvesting operations basically consist of the components of felling trees, bucking, skidding, loading and log transportation. Timber harvesting operations are very risky to the safety of workers. Errors caused by negligence and inappropriate actions of the operator with the applicable provisions can cause a problem called work accident [1]. It is necessary for the field supervisors to meet and discussions to release the workers stress and psychological workers [2]. Logging activities are mostly done using mechanical cutting tools, ranging from chainsaws to harvester [3]. Several studies have shown that timber harvesting causes environmental damage including to residual stands and forest biomass $[4,5,6]$.

The work environment factors that influence work safety are the physical work environment and the provision of equipment that can be used as a means of prevention and protection [7]. Protection of employees or workers who serve working tools can cause accidents, by providing protection equipment appropriate and good. Protective equipment for 
example: gas mask, glass welding eyes, gloves, safety helmets, fire retardant clothing and shoes.

An understanding of occupational safety and health is very important. This is related to productivity. The demand to continually show commitment to occupational safety and health is actually intense in Indonesia. In the current era, every company that produces products must meet one of the requirements, namely Environment Health and Safety. These evaluations play a role in improving the existing OSH management system. The purpose of this study was to determine loggers perceptions of the application of occupational safety and health (OSH) based on aspects of knowledge, skills and attitude in logging activities in the industrial timber plantations areas, North Sumatra, Indonesia.

\section{Research Method}

The materials used in research are stationery writing, questionnaire, camera and calculator. Observations in the field are carried out with interviews against related parties such as companies, workers and operators. This assessment is carried out using a qualitative questionnaire that is by descriptive analysis. The results of the interview are measured using a Likert scale obtained from the questionnaire. Data obtained from the interview questionnaire were processed using the Spearman rank test and the Wilcoxon test.

\subsection{Data collection}

This research was conducted at PT. Toba Pulp Lestari area, North Sumatra, Indonesia. Interview process was carried out through a question and answer session using a questionnaire. The questionnaire used was a questionnaire derived from previous OSH research using valid question variables and refined the question variables.

The choice of answers in the questionnaire for each respondent is determined based on a Likert scale. It has been given a certain weight according to the answer to the question. Likert scale which is an ordinal measurement scale that gives results in the form of ranking and serves to show respondents' responses (self-assessment) to the questions.

Observation activity is a method of collecting data obtained through direct observation of the real conditions in the work environment related to the competence in applying OHS in the fields of felling and bucking, skidding and logging transportation. The value set for the respondent's choice of answers includes: knowledge, skill, and attitude.

To support the data analysis activities, a set of computers is used in processing with Microsoft Excel software applications and SPSS (Statistics Program for Social Science) 19.0 for windows. The research data processed and analyzed are primary data obtained from the results of questionnaires and interviews with field supervisor and chainsaw operators.

\section{Results and Discussion}

\subsection{Characteristics of respondents}

Respondents are workers or employees as well as partners in the field of timber harvesting, consisting of field supervisors and operators of chainsaw in timber harvesting areas. Respondent characteristics can be seen in figure 1. 


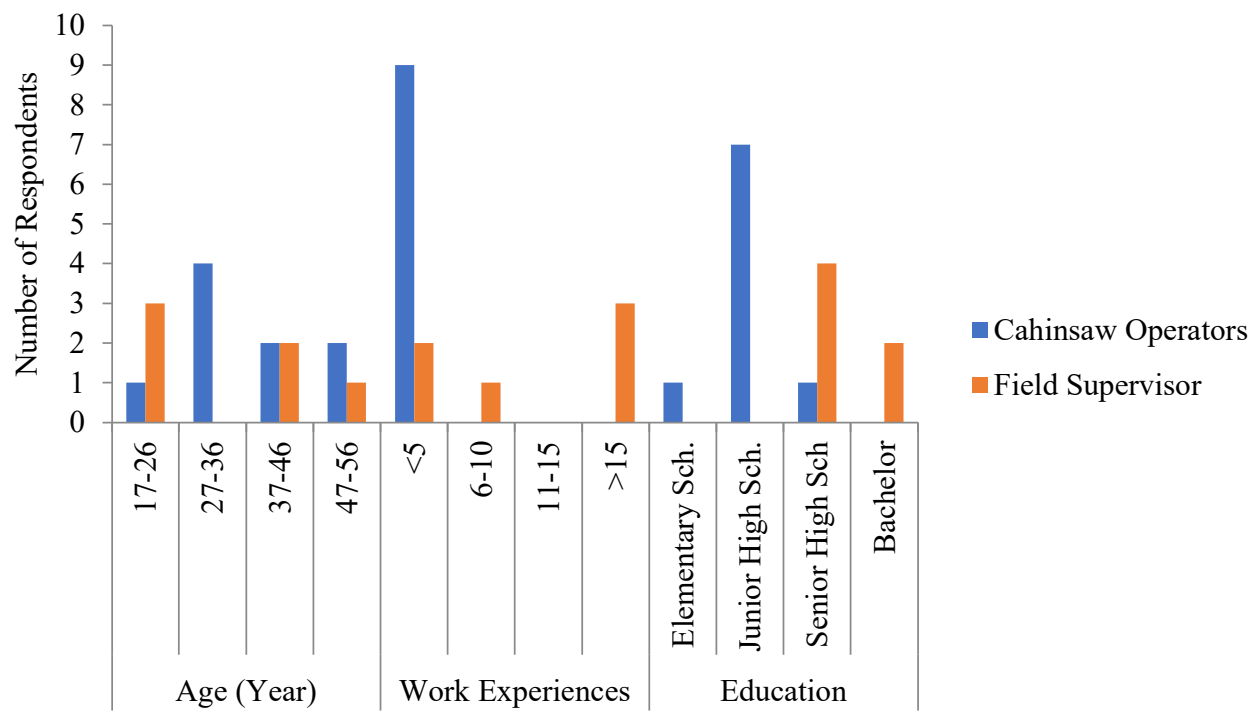

Fig. 1. Characteristics of respondents based on age, work experience and education.

Based on Figure 1, it can be seen that the average the chainsaw operators was in age range 17-56 years old. The oldest age was 69 years old. Most of the working age are in the productive age, namely 17-26 years old with varied work experience ranging from the new 20 working days found in the skidding respondents to the longest that is 27 years found in the logging respondents. This is the same as research conducted by [8] which states that the highest percentage of workers at PT. Toba Pulp Lestari, Tbk Tele sector is at the age of $<25$ years was $53.06 \%$, the age of $25-40$ years was $38.77 \%$ and $>40$ years was $8.16 \%$, respectively.

Field supervisor is an employee who is directly bound to the company PT. Toba Pulp Lestari while chainsaw, skidding and truck driver operators as wood carriers are the partners of PT. Toba Pulp Lestari, in wood harvesting activities. The field supervisor work experience $>15$ years has shown that the field supervisors are employees who have relatively good work experience. In terms of the level of education possessed by timber harvesting employees at PT. Toba Pulp Lestari areas was $66.67 \%$ field supervisors have a high school level education while for loggers and skidding, namely $77.78 \%$ and $58.33 \%$ have a junior high school level education and $45.45 \%$ of the transport employees only have an elementary level education.

\subsection{Competency Analysis of OSH Application of Chainsaw Operators}

Chainsaw operators and standard based assessments by Wilcoxon test. In determining the magnitude and direction of the relationship between standard based assessments by assessment according to respondents, then an analysis of the value is carried out the average of respondents' answers is based on questions that are already valid and reliable. The amount of the difference in the average value of the competency aspects of the faller and judgments based on standards can be seen in Table 1 . 
Table 1. Competency aspects in the application of OSH between standard based assessments.

\begin{tabular}{llllllllll}
\hline & \multicolumn{3}{c}{ Knowledge } & \multicolumn{3}{c}{ Skill } & \multicolumn{3}{c}{ Attitude } \\
& SA & CBA & Difference & SA & CBA & Difference & SA & CBA & Difference \\
\hline $\begin{array}{l}\text { Total of } \\
\text { value }\end{array}$ & 44.88 & 36.54 & -8.34 & 45.88 & 36.45 & -9.43 & 45.11 & 33.91 & -11.2 \\
Average & 4.08 & 3.23 & -0.85 & 4.17 & 3.31 & -0.86 & 4.1 & 3.08 & -1.02 \\
\hline $\begin{array}{l}\text { Note: SA }= \\
\text { (objective self-assessment (subjective assessment/perception of respondents); CBA }=\text { control based assessment }\end{array}$
\end{tabular}

Table 1 showed that the knowledge aspect of chainsaw operators has a difference. It is a significant difference which is shows that aspects of knowledge owned by chainsaw operators are different by standard based assessment. Skill aspect and attitude there is a difference of 0.86 and -1.02 , respectively.

Results of the analysis on the competency of each chainsaw operators i.e. knowledge, skill and attitude have values of 4.08, 4.17 and 4.1, respectively. Compared with the average Likert scale the value is at level of knowing, can and sometimes. To find out there is significant differences between respondent's perceptions and standard based assessment, it can be seen in Table 2 .

Table 2. Chainsaw operator's perceptions and based assessments standard by Wilcoxon test.

\begin{tabular}{llll}
\hline Value & Knowledge & Skill & Attitude \\
\hline $\mathrm{Z}$ & -2.937 & -2.938 & -2.937 \\
Asymp. Sig. (2-tailed) & 0.003 & 0.003 & 0.003 \\
$\mathrm{~A}$ & 0.05 & 0.05 & 0.05 \\
\hline
\end{tabular}

Note: $\mathrm{H}_{0}$ is accepted if Asymp. Sig) $>\alpha$ value; $\mathrm{H}_{0}$ is rejected if Asymp. Sig $)<\alpha$ value

Based on Table 2, it can be seen that the competency aspect (knowledge, skill and attitude) have a probability value of 0.003 . It indicates that there are significant differences between chainsaw operator's perceptions with a standard based assessment $\left(\mathrm{H}_{0}\right.$ rejected).

\subsection{Relationship between competency aspects of chainsaw operators}

The closeness of the relationship between aspects of the competence of chainsaw operators as strategies to improve competency aspects can be seen in Table 3.

Table 3. Spearman correlation test results among competence aspects of chainsaw operators.

\begin{tabular}{|c|c|c|c|c|c|}
\hline & & & Knowledge & Skill & Attitude \\
\hline \multirow[t]{6}{*}{$\begin{array}{l}\text { Spearman's } \\
\text { rho }\end{array}$} & Knowledge & $\begin{array}{l}\text { Correlation } \\
\text { coefficient }\end{array}$ & 1.000 & 0.252 & 0.273 \\
\hline & & Sig. (2-tailed) & & 0.454 & 0.416 \\
\hline & Skill & $\begin{array}{l}\text { Correlation } \\
\text { coefficient }\end{array}$ & 0.252 & 1.000 & -0.106 \\
\hline & & Sig. (2-tailed) & 0.454 & . & 0.757 \\
\hline & Attitude & $\begin{array}{l}\text { Correlation } \\
\text { coefficient }\end{array}$ & 0.273 & -0.106 & 1.000 \\
\hline & & Sig. (2-tailed) & 0.416 & 0.757 & . \\
\hline
\end{tabular}


Based on the calculation of Spearman's rank correlation in Table 3, there is a significant correlation between aspects of skill with attitude, aspects knowledge with skills and knowledge with attitudes with each value was $0.252,0.273$ and 0.106 , respectively. Probability value Sig. (2-tailed) each namely was $0.454,0.416$ and 0.757 , respectively. Results of the analysis note that no there is a real relationship between the aspects tested.

Knowledge aspect and attitude aspect are related to each other because it has a significant correlation. The skill aspect has a relationship with attitude aspect, so to improve aspects one will improve the other aspects as well. For chainsaw operators, there is a lot of risk that accidents will occur, and the need for guaranteed protection by the provision of personal protective equipment. Employees who serving work tools that can cause accidents, by the way provide appropriate and good protection tools [7]. Protective gear for example: gas masks, welding goggles, gloves, safety helmets, anti-wear fire, shoes and earmuffs.

Based on the objective assessment carried out the application of OHS is not can be fully implemented by workers despite personal protective equipment (PPE) has been provided by the company. This is the same thing with [9] states that deficiencies found in the use of PPE that is because employees are lacking feel comfortable using PPE, this can be seen from the number of accidents happened not yet reached Zero Accident. However based on real conditions in the field no workers were found use PPE complete with the reason not familiar with the PPE and feel disturbed when using these types of PPE. That matter in accordance with research [10] work accidents in industrial areas Pulo Gadung Jakarta workers who are already obedient use the PPE (tools personal protection).

\section{Conclusions}

This research indicates that there are significant differences between chainsaw operator's perceptions with a standard based assessment. Training, counseling and setting strict rules can improve aspects of competence in the application of occupational health and safety (OHS). Based on the objective assessment carried out the application of OHS is not can be fully implemented by workers despite personal protective equipment (PPE) has been provided by the company.

\section{Acknowledgments}

Thanks to the Rector of Universitas Sumatera Utara for funding this research through TALENTA USU 2019 research scheme. Thanks also to PT Toba Pulp Lestari for facilitating this research.

\section{References}

[1] Armanusah, A.S. Increased occupational health and safety (OSH) on forestry workers (case study: IUPHHK-HA PT. Sarmiento Parakantja Timber, Central Kalimantan). IPB University. Bogor (2009). 
[2] Godspower, I., Tsaro, K. Health risk behaviors of employees in selected oil servicing companies in Port Harcourt. International Journal of Occupational Safety and Health. (2019).

[3] Conway, S. Logging practices. San Fransisco, US. (1978).

[4] Purwoko A., Muhdi, Hanafiah A.S. Residual stand damages caused by conventional and reduced impact timber harvesting in the natural forest. International Journal of Mechanical Engineering and Technology (IJMET). (2018).

[5] Muhdi, Sahar, A., Hanafiah, D.S., Zaitunah, A., Nababan, F.W.B. Analysis of biomass and carbon potential on eucalyptus stand in industrial plantation forest, North Sumatra, Indonesia. IOP Conference Research of Earth Environtment Science. (2019).

[6] Latifah, S., Muhdi, Purwoko, A., Tanjung, E. Estimation of aboveground tree biomass Toona sureni and Coffea arabica in agroforestry system of Simalungun, North Sumatra, Indonesia. Biodiversitas. (2019).

[7] Moenir, A. S. Humane and organizational approaches to coach staffing. PT. Gunung Agung. Jakarta. (1983).

[8] Nasution, Y. Occupational safety and health in timber harvesting activities (case study PT. Toba Pulp Lestari, Samosir, North Sumatra). Universitas Sumatera Utara. (2009).

[9] Ricatsen, M., Erlina, Akmal. Health and safety analysis using the hazard and operability (Hazop) method at PT. Karya Terang Sedati. Industrial Engineering of UPNV. Sidoarjo East Java. (2012).

[10] Riyadina, W. Work accidents and injuries experienced by workers industry in the Pulo Gadung Industrial Area. Makara Journal. (2007). 